\title{
RELEVANCE OF MARKET INFORMATION SYSTEM TO ENVIRONMENT PROTECTION
}

\author{
Bishnu D. Awasthi, MSc. Agri. Econ. ${ }^{7}$
}

\begin{abstract}
Market information is an important facilitating function in a marketing system. It facilitates marketing decisions, regulates the competitive market processes and facilitates marketing mechanisms. To increase consumption, it is necessary to develop marketing channels. After production, marketing is the most important function, which consists of assembling, processing and distribution of marketable surplus. An efficient marketing information system can manage, for timely delivery of product, reduce marketing costs and increase production and productivity and make the market yard healthy and hygienic. The existing practices of vegetable marketing system consists only the collection of selling price of different vegetables and fruits, volume of arrival and source of origin. Fruits and vegetables are bulky and perishable by nature and need immediate disposal in the market having with clean and proper packaging. If it is not properly done, it generates wastes in the market and pollute the locality. Efficient vegetable market information system can minimize the waste induced problems in the vegetable markets. Environmental policies are influenced by economic, social, and political forces. To ensure that the execution of these policies protects human health and ecosystems effectively and efficiently, scientific and technical information need to be an integral consideration from the earliest stages of policy making.
\end{abstract}

\section{Introduction}

Agriculture sector is a dominant player of the Nepalese economy. It accounts about 38 per cent of the gross domestic product and employs 65 per cent of the total population. Rapid population growth amidst a scarce supply of fertile land has increased pressure on the natural resources. As a result, encroachment of the marginal lands in the hills and mountains for agricultural use has increased. Similarly conversion of prime agricultural land to other nonagricultural uses in the plains primarily for urbanization or industrialists use is causing grave environmental repercussions. The rapidly building pressure among population land and productivity and others has been among the factors underlying the social tension. The close linkages between a limited resource base, rapid population growth, environmental degradation, low level of social development, and widespread poverty present a complex development challenge that requires a well-integrated strategy to ensure economic development and poverty alleviation on a sustainable basis.

In 1995, Nepal approved a 20 year Agriculture Perspective Plan (APP). It is designed to accelerate agricultural growth for fast-track poverty reduction in a sustainable way. The Tenth Plan (2002-2007), which is also the Poverty Reduction Strategy Paper (PRSP) of Nepal, has also identified poverty reduction as the sole goal with the highest priority to the agriculture sector. Due to this reason the traditional farming slowly is being transformed into a commercial enterprise.Such enterprise generates produces mainly for marketing. The dissemination of accurate and timely marketing information is vital in helping farmers make good marketing decisions to reduce marketing costs and that increase producers' share to consumers' rupee.

\footnotetext{
${ }^{7}$ Senior Agri. Economist, Planning Division, Ministry of Agriculture and Co-operatives, Singhdurbar. Email : bdawasthi@hotmail.com
} 


\section{Objectives}

The main objective of this paper is to assess the importance of marketing information system in relation to commercial vegetable production and environmental protection.

\section{Vegetable Production}

Vegetables are important sources of energy, protein, vitamins and minerals. They are considered as protective food since they contain higher amount of vitamins and minerals. However, in Nepal, cereals provide major bulk of the daily diet which provides larger amount of energy (88\%). Due to the nutritive value of vegetables and health awareness of the consumer, the per capita consumption of vegetables in Nepal has increased from 49 $\mathrm{kg} /$ person/year/ to $60 \mathrm{~kg} /$ person/year in the last ten years (Table 1), but remains still below the human vegetable nutritional requirement, of $104 \mathrm{~kg} /$ person/year. Cereal based diet is one of the main causes of malnutrition. Lack of protective nutrition has resulted into poor standards of health in the country.

Table 1. Area, Production and Productivity of Vegetables

\begin{tabular}{|l|l|l|l|}
\hline Year & Area (ha) & Production $(\mathrm{mt})$ & Yield $(\mathrm{mt} / \mathrm{ha})$ \\
\hline $1990 / 91$ & 140500 & 1074650 & 7650 \\
\hline $1995 / 96$ & 144368 & 1327298 & 9194 \\
\hline $2000 / 01$ & 157162 & 1652979 & 10518 \\
\hline $2005 / 06$ & 189832 & 2190100 & 11537 \\
\hline Annual growth rate $(\%)^{*}$ & 2.1 & 4.97 & 2.80 \\
\hline
\end{tabular}

Source: MOAC, 2006

To increase consumption, it is necessary to develop marketing channels together with vegetable production. After production, marketing is the most important function, which consists of assembling, processing and distribution of marketable surplus. An efficient marketing information system can manage, timely delivery of product, reduce marketing costs and increase the production and productivity and make the market yard healthy and hygienic.

Production of vegetables is a traditional custom in the Nepalese community, particularly for culinary purpose. Vegetables, the main source of minerals, vitamins and protein, are the most important constituents of the Nepalese diet. Vegetables are one of the important short seasonal and major components of Nepalese agricultural system. The development of vegetables in Nepal started during early forties. During fifties, a wide range of temperate and tropical vegetables was introduced and tested for their adaptability and seed production in different ecological zones of Nepal. However, the vegetable development activities received priority since Fifth Five Year Plan (1975/76 to 1979/80). In 1972 Vegetable Development Division (VDD) was established within Department of Agriculture with the objectives to conduct research, generate and promote new technology and increase the production. The rapid increase of vegetable production and marketing in the country is the output of this effort (VDD, 2004).

Vegetables come under a national priority because they are much more important than any other horticultural crops; they are less risky to grow than fruits and are annual and semiannual in cultivation. Women and men participate in vegetable production and have got an 
opportunity to increase their household income vis-à-vis women empowerment. There are more than 247 cultivated vegetable crops and more than 50 crops are common in Nepal. Due to wide range of climatic conditions ranging from tropical to alpine temperate, it is possible to grow almost all types of vegetables in the nation. The common vegetables grown in Nepal are:

- Cole crops: cauliflower, cabbage, broccoli, Chinese cabbage

- Solanaceous fruits: sweet and hot pepper, annual and perennial chili, brinjal, tomato

- Root, tuber and bulb crops: radish, turnip, carrot, potato, yam, taro, onion, garlic, sweet potato, ginger, turmeric

- Legume crop: fresh bean, cowpea, asparagus, bean, broad bean, pea, lime bean

- Cucurbits: cucumber, pumpkin, squash, bitter guard, sponge guard, ridge gourd, wax gourd, pointed gourd, bottle gourd, watermelon, muskmelon, snake gourd

- Leafy vegetables: broad leaf, mustard, beef spinach, cress, spinach, coriander, lettuce, mustard leaf, swisschard

- Other vegetables: okra, etc,

Of the above, cauliflower is the major crop with large acreage and production.

\section{Vegetable Marketing}

Marketing of vegetable products begins at the farm when the farmer plans his production to meet specific demands and market prospects. The harvester's product can not usually go directly to the consumer. The production site is likely to be away from the place of consumption. Thus the transportation is required to bring the product. Vegetable production is generally seasonal while consumption is regular and continuous throughout the year. Thus, storage is required to adjust supply to demand. Similarly, a product is rarely in a form acceptable to consumers. It must be sorted, cleaned and processed in various ways, and must be presented to the consumer in convenient quantities for sale. Moreover, the farmer expects payments when his produce leaves his possessions. Some financial arrangement must be made to cover all the various stages until the retailer sells the product to the consumer. It is the marketing that provides such services between production and consumption.

In Nepal, there are 33 market centers for fruits and vegetables, 21 collection centers, 8 wholesale markets and 4 retail markets constructed in the initiation of government within the country and some others managed by the private sector. There are number of vegetable markets within Kathmandu Valley. Out of them Kalimati Vegetable Wholesale Market (an Government Undertaking) is the biggest market of Nepal. Similarly other fruit and vegetable markets are Harsha Fruit Market, Balkhu (Private Sector) and Kishan Bazar Sewa, Tukucha (private sector). In addition, there are some roadside markets used by secondary wholesalers, retailers, street hawkers and farmers.

\section{Development of Marketing Information System in Nepal}

Vegetable marketing information system (VMIS) may be defined as the method of generating information on time to assist farmers to take appropriate decisions for selling their produces at the appropriate time. These information aid farmers, traders government officials and consumers to perform their activities effectively and efficiently causing increased competition in the markets.

Development of marketing information system was initiated by the Agricultural Economics Section of the then Department of Agriculture in a limited scale in 1960. This section was 
upgraded as Economic Analysis and Planning Division under MOAC with added function of collection and compilation of market prices. This activity was expanded in terms of geographic coverage, type of prices, and commodity coverage after the establishment of the then Department of Food and Agricultural Marketing Services (DFAMS). The Department also carried out the analysis of the information. One of the major features of DFAMS market information system was mainly to serve the policy makers and planners. Wholesale and producer price collection was limited. The dissemination of information was greatly improved. However, the information was then not disseminated through public media for wider public uses.

Marketing information services are being delivered to various target groups by the government, semi-government, private sector and nongovernmental organization. Every organization has made efforts to provide quality information and enhance the management capacity of the concerned stakeholders. Most often, vegetable development projects, whether of government or non governmental organization, has provided marketing information to the producer farmers. The following table no 2 shows the detail:

Table 2 Development of Marketing Information System in Nepal.

\begin{tabular}{|c|c|c|}
\hline Year & Institution/Organization & Activities \\
\hline 1960 & $\begin{array}{l}\text { Agriculture Economics Section } \\
\text { (AES), Department of } \\
\text { Agriculture }\end{array}$ & $\begin{array}{l}\text { Collection retail prices of some agricultural } \\
\text { commodities from Kathmandu Valley }\end{array}$ \\
\hline 1966 & $\begin{array}{l}\text { Economic Analysis and Planning } \\
\text { Division (EAPD), Ministry of } \\
\text { Food and Agriculture }\end{array}$ & $\begin{array}{l}\text { Collection and dissemination of market information to } \\
\text { commercially important districts covering major } \\
\text { agricultural commodities. }\end{array}$ \\
\hline 1972 & $\begin{array}{l}\text { Department of Food and } \\
\text { Agriculture Marketing Services } \\
\text { (DFAMS) }\end{array}$ & $\begin{array}{l}\text { Collection and Publication of price information of } \\
\text { agricultural commodities including fruits and } \\
\text { vegetables. }\end{array}$ \\
\hline 1980 & $\begin{array}{l}\text { Early Warning Project (EWP) } \\
\text { funded by FAO and UNDP }\end{array}$ & $\begin{array}{l}\text { Initiated price information collection of different } \\
\text { agricultural commodities }\end{array}$ \\
\hline 1982 & $\begin{array}{l}\text { Department of Food and } \\
\text { Agriculture Marketing Services } \\
\text { (DFAMS) }\end{array}$ & $\begin{array}{l}\text { Started early warning project with the support of FAO } \\
\text { initiated the use of computer technology for the first } \\
\text { time in processing and reporting agricultural marketing } \\
\text { information services. }\end{array}$ \\
\hline 1987 & $\begin{array}{l}\text { Department of Food and } \\
\text { Agriculture Marketing Services } \\
\text { (DFAMS) }\end{array}$ & $\begin{array}{l}\text { Only one price of each agricultural commodity collected } \\
\text { on daily basis and recorded in the registered book. }\end{array}$ \\
\hline 1991 & $\begin{array}{l}\text { Department of Food and } \\
\text { Agriculture Marketing Services } \\
\text { (DFAMS) }\end{array}$ & $\begin{array}{l}\text { Minimum and maximum prices of agricultural } \\
\text { commodities collected and average price was } \\
\text { calculated. }\end{array}$ \\
\hline 1992 & $\begin{array}{l}\text { Department of Food and } \\
\text { Agriculture Marketing Services } \\
\text { (DFAMS) }\end{array}$ & $\begin{array}{l}\text { Price of fruits and vegetables of Kalimati Market are } \\
\text { being regularly aired by Radio Nepal in morning hours. }\end{array}$ \\
\hline
\end{tabular}




\begin{tabular}{|l|l|l|}
\hline Year & Institution/Organization & Activities \\
\hline 1995 & $\begin{array}{l}\text { Kalimati Fruits and Vegetables } \\
\text { Wholesale Market Development } \\
\text { Board }\end{array}$ & $\begin{array}{l}\text { Established and started collection of prices of different } \\
\text { fruits and vegetables at one time (afternoon only) }\end{array}$ \\
\hline 1997 & $\begin{array}{l}\text { Market Development } \\
\text { Directorate (MDD), Department } \\
\text { of Agriculture }\end{array}$ & $\begin{array}{l}\text { Price of five wholesalers of each agricultural commodity } \\
\text { collected. }\end{array}$ \\
\hline 1998 & $\begin{array}{l}\text { Agro-enterprise Center } \\
\text { (AEC)/FNCCI }\end{array}$ & $\begin{array}{l}\text { Started collection of market information of agricultural } \\
\text { commodities at local and international level. }\end{array}$ \\
\hline 1998 & $\begin{array}{l}\text { Kalimati Fruits and Vegetables } \\
\text { Market Development Board }\end{array}$ & $\begin{array}{l}\text { Prices were collected twice a day (Morning 7-8 AM and } \\
\text { Afternoon 1-2 PM) }\end{array}$ \\
\hline 2001 & $\begin{array}{l}\text { Kalimati Fruits and Vegetables } \\
\text { Market Development Board }\end{array}$ & $\begin{array}{l}\text { Morning wholesale prices of fruits and vegetables aired } \\
\text { through Radio Nepal at the same evening. } \\
\text { fruits and vegetables aired through Radio Nepal in the } \\
\text { next day evening at 6:35 PM. }\end{array}$ \\
\hline
\end{tabular}

Source: Awasthi, 2003

Although the traders use telephone, mobile phone and email services to get market information through their own network, majority of the small farmers not associated with the project activities have no access to marketing information services. Since the cost of marketing information to an individual farmer becomes high, information services provided by public and nongovernmental sector will play a vital role for enhancing the capability of the small farmers.

At present, various agencies are working for the collection, analysis and dissemination of agricultural marketing information services according to their requirements. Agriculture Business promotion and Marketing development Directorate (ABMDD) of Department of Agriculture is the main agency. Other agencies like Agro Enterprise Centre (AEC), Kalimati Fruit and Vegetable Market Development Board (KFVMDB), Trade Promotion Centre (TPC), National Planning Commission (NPC), Nepal Rastra Bank (NRB), District Agricultural Development Office (DADO) are also engaged in this activity (FAO 1999).

Beginning from the $26^{\text {th }}$ December 1997, the wholesales price of vegetable traded in Kalimati Fruit and Vegetable Market are collected early in the morning and afternoon. The arrival of each commodity is estimated everyday. Daily prices are published in the notice board and bulletin daily. Besides the volume of arrivals the prices are published through its weekly, monthly and annual bulletins. The collected wholesale price of selected vegetables in Kalimati Wholesale market is aired in the next morning by Radio Nepal. The cost of broadcasting daily prices is borne by ABMDD. The wholesale traders and collectors are major target groups of information system. It is capable of catering their need. The central information system is weak and has even no linkages with districts and thus has by -passed major producers.

Market information is collected through various means and utilized in deciding time, market place and volume of supply by the farmers. Farmers have utilized the marketing information 
provided by Radio Nepal, newspapers, telephone, neighbors and friends and market center observation (in advance). Farmers display prices of Kalimati wholesale market aired through Radio Nepal as selling prices of wholesalers at the market centres. The information broadcasted through Radio Nepal include only selling price of wholesalers, not their buying price. Farmers making marketing decisions according to this information were confused as the prices they receive are actually different from the broadcasting prices.

\section{Impact on Environment}

Due to fast growing of vegetable markets Kathmandu valley, concerned organizations are unable to cope with the increasing demand for solid waste management. Kalimati Vegetable Wholesale Market has the major problem of waste management. Secondary wholesalers, retailers, bicycle vendors and consumers purchase vegetables and throw the damaged and unused parts in the market. Damaged vegetables are the major causes of waste generation in the market.

The existing vegetable marketing information system of Kalimati Fruits and Vegetable Market Development Board focuses only price, volume and source of arrival of vegetables and fruits. Being a fruit and vegetable market, the waste disposal is a big problem from the sanitation point of view. Though this is a huge source of organic wastes, potential for recycling these wastes into composts and similar useful commodities is immense. The average daily wastes generated in Kalimati Vegetable Market are about $10 \mathrm{mt}$. It has polluted the market badly and looks unhygienic. This type of situation is common in other vegetable markets within Kathmandu Valley also. The reason behind is that farmers pick up their vegetables along with unnecessary parts and packaging materials which generate much more waste in the market. This situation can be minimized through the development of efficient market information system by disseminating the information relating to cleaning grading and packaging.

\section{Policy Issues}

Efforts to commercialize horticulture production in Nepal started after 1970.The ten-year Agriculture Development Plan formulated in 1973 emphasized development of commercial horticulture along the highway corridors. Realizing the importance of market development, Government of Nepal has been effortful in providing agricultural marketing services since the Fourth Five Year Plan Period. Major surplus fruits and vegetables are marketed in domestic markets. Nearly 40 per cent of marketable surplus produces in Indian bordering districts go to Indian markets, either through Indian traders (assemblers, hawkers and Urban wholesalers, agents) or local farmers.

In the $10^{\text {th }}$ five year (2002-2007) plan, the government explicitly placed the solid waste management in the forefront of the national planning agenda. The plan highlighted the problem of a final disposal site as a major challenge in solid waste management, especially in the Kathmandu Valley. It has therefore, categorily stated that priority will be given to the infrastructure development of a long-term landfillsite in Okharpauwa and this construction is included in the list of priority projects to be implemented by Ministry Of Local Development within the current five year framework.

The policy of waste management advocates tempering off the waste problem through decomposing and recycling at local level. In case of organic wastes, of vegetables, the most appropriate way of managing is by composting, and adopting environmentally and agriculturally reasonable practice of management. That is the way where our whole attempt to settle the issue of waste should be link up which will be beneficial to environment and supporting to agriculture sector. Market information system should be developed to educate 
the farmers to clean their vegetables at farm level and make the compost of vegetables residues. Agricultural market information system in Nepal is not yet well developed and not client oriented in comparison to other Asian countries.

\section{Marketing Information System in Asia}

Different countries have developed different systems and invested in varying amount to build up the system with variations only partly related to the amount of money invested in the system. They are reflected in planning priorities and the types of commodities produced.

Most countries in Asia operate a market information service with the express aim of promoting efficient marketing and raising farm incomes. The form it takes varies according to the level of economic development, and especially the extent to which agriculture has changed from subsistence to commercial farming.

In Indonesia, Japan, Korea, Malaysia, Philippines, Taiwan ROC and Thailand, agricultural market information is a national government service which receives regular government funding. It is usually run by the Ministry of Agriculture or its equivalent, organization sometimes by several Ministries (for example in Thailand, marketing information it is jointly operated by the Ministry of Agriculture and Cooperatives and the Ministry of Commerce). There are often additional independent services for particular interest groups. For example, Japan has an information service operated by ZEN-NOH, the national farmers' cooperative organization. Malaysia, a major agricultural exporter, is the only country not to have a single government service covering all major crops. Instead, each major export crop has its own price information service run by the special government agency that is also responsible for extension and research for that crop. Information about vegetables and other domestic food items in Malaysia is the work of FAMA, the Federal Agricultural Marketing Authority.

\section{Forecasting}

Forecasting of future demand to guide farmers in their production planning is one of the most useful, tools but also one of the most difficult tasks in market information service. In Thailand, Ministry of Commerce and Ministry of Agriculture and Cooperatives have jointly set up an on-line information system which collects marketing information from a variety of sources in both the public and private sectors. The Thai government is now analyzing supply and demand in order to distinguish the crops which continuously face marketing problems for which production needs to be reduced.

\section{Disseminating Market Information to Farmers}

National marketing information systems usually provide price information through the mass media such as newspapers and radio. However, it is not clear how useful such information is to farmers.

In most market information systems, regional data are transmitted to a central national facility where they are processed and amalgamated with similar data from all over the country. The result is useful to those working for central government agencies, which need to know what is happening in the entire country. It is of less value to the farmers in rural areas which provide the original data.

Farmers are interested mainly in prices in local markets where they sell their goods. For efficient dissemination to farmers, market information services need to be decentralized, especially in remote areas where there are wide regional price differences. Thailand is now planning to develop a database system at a provincial level so that the relevant agencies can operate the system more efficiently and conveniently. The AGMARIS Project in the Philippines 
has also decentralized the market information system so that there will be improved access in the provinces. Indonesia's market information system already uses provincial offices to distribute locally collected data to radio stations, newspapers etc., and to maintain "Price Boards" which are displayed in collection areas and updated every day.

\section{Conclusion}

Vegetable products are less risky, fast growing and best sources of income in comparison to other cereal crops. Due to the market access and increasing demand of vegetables, area production and productivity of vegetables is also increasing over the years. According to the data of Kalimati Fruits and Vegetable Market Development Board local production of vegetables makes a supply of $87 \%$, while only $13 \%$ is imported from India and others countries. Before 15 years the local production met the demand of only $13 \%$ the rest was imported. An efficient Market information system can play a vital role to increase the income of producer farmers and regularize supply in the market.

The existing vegetable market information system of Kalimati Fruits and Vegetable Market Development Board concentrates only on price, volume and sources of arrival of vegetables and fruits. Being a fruit and vegetable market, the waste disposal is a big problem from the sanitation point of view, although this is a huge source of organic wastes and potential for recycling into composts and similar useful commodities.

The policy of waste management should include of tempering off the waste problem through decomposing and recycling at local level. In case of organic wastes, of vegetables, the most appropriate way of managing is by composting, and adopting environmentally and agriculturally reasonable practice of management. This is the way where our whole attempt to settle the issue of waste should be designed, which will be beneficial to environment and supporting to agriculture sector. Market information system should be developed to educate the farmers to clean their vegetables at source and make the compost of vegetables residues

\section{Recommendations}

Advanced information and communication technology is suited to government collection and analysis of large quantities of data. It is of little relevance in a direct information service for farmers.It might be valuable if suitable intermediaries are used. Generally speaking, farmers benefit more from simple technology which communicates information in a lucid and relevant way. It should be noted that farmers are interested, not only in current price information, but also in marketing issues like waste generating problems and demand forecasts.

- There is wide price variation according to quality. Fruit and vegetable prices are particularly influenced by quality, and size. The lack of a uniform national grading system is a major constraint to the development of an efficient national market information service.

- Farmers must be able to seek out and compare the information available for different outlets if they are to sell to their best advantage. Price information is less useful if there is only a single market outlet or if, farmers are price takers rather than price seekers. Where there is a very wide gap between the farm gate price and the price paid in wholesale markets and by consumers, marketing information can help narrow the gap provided an efficient marketing systems in place.

- It follows from the previous point that the effectiveness of market information largely depends on the structure of the overall marketing system. 
- Vermicomposting and Effective Microorganizm (EM) should be taken as the environmentally best methods of decomposing of vegetable waste by the concerned organizations."Marketing information is a means to an end, not an end in itself."

\section{REFERENCES}

1. APROSC. 1995: Nepal Agriculture Perspective Plan. National Planning Commission, Singha Durbar John Mellor Associates Kathmandu, Nepal.

2. AWASTHI, B, D, 2003: Vegetable Production and Marketing in Kathmandu Valley. Community Rural Develop ment Society, Devinagar, Kathmandu.

3. FAO, 1995: Vegetable Supply to Selected Urban Centers in Nepal, Bharatpur Municipality. Food and Agriculture Organization of the United Nations, Kathmandu, Nepal. 13 p.

4. FAO, 2003: Improving Agricultural Marketing Information System. A report on Regional Seminar organized by FAO/AFMA/MYANMAR 3-8 February, 2003, Yangon.

5. FAO. 1998: Proceedings of the National Seminar on Fruit and Vegetable Marketing in Nepal, September 15 and 16, 1998. Food and Agriculture Organization on the United Nations, Kathmandu, Nepal. pp 1-35.

6. FAO. 1999: Proceedings of the workshop on Marketing Information held during August 30, 1999 in Kathmandu. FAO, Nepal. 157 p.

7. HMG/N. 2000: Agricultural Marketing Development Project in the Kingdom of Nepal. JICA/MOAC Nepal.

8. HMG/N. 2006: Statistical Information on Nepalese Agriculture. Agri-Business Promotion and Statistics Division, MOAC. Singha Durbar, Kathmandu, Nepal. 23 p.

9. Kaini, B. R. and R., A. Werner, 1998: A Market Oriented Approach to Horticulture Production in Proceedings of the National Workshop Market Oriented Production Approach. Nepal Horticulture Society, Kathmandu. pp. 74-77

10. KFVMDB. 2004: Annual Progress Reports. Kalimati Fruits and Vegetable Market development Board, Kathmandu, Nepal.

11. KFVMDB. 2005: Annual Progress Reports. Kalimati Fruits and Vegetable Market development Board, Kathmandu, Nepal.

12. Mathema, P.R., 1998: National Agricultural Marketing Information System: objectives and activities. In" Proceedings of the National Seminar on Agricultural Marketing Information System in Nepal" held during June 10 and 11, 1998 in Kathmandu. FAO, Kathmandu, Nepal.

13. MDD. 2001: Agricultural Marketing Information Bulletin. Marketing Development Directorate. Harihar Bhawan, Lalitpur, Nepal. 148 p.

14. MDD. 2003: Assessment of Benefits Achieved by Farmers' Through the Development Agricultural Market Center. MDD/DOA/MOAC Nepal.

15. Werner, R. A. and Subedi, D.K., 1991. Post-harvest Losses Assessment in Selected Vegetables in Nepal. Tomato, cabbage and cauliflower, HMG/FAO Fresh Vegetables and Vegetables Seed Production Project, Nepal. 